\title{
Anti-Atherogenic Effects of Vaspin on Human Aortic Smooth Muscle Cell/Macrophage Responses and Hyperlipidemic Mouse Plaque Phenotype
}

\author{
Kengo Sato ${ }^{1}$, Remina Shirai ${ }^{1}$, Maho Yamaguchi ${ }^{1}$, Tomoyuki Yamashita ${ }^{1}$, Koichiro Shibata ${ }^{1}$, \\ Taisuke Okano ${ }^{1}$, Yusaku Mori ${ }^{2}$, Taka-aki Matsuyama ${ }^{3,4}$, Hatsue Ishibashi-Ueda ${ }^{4}$, \\ Tsutomu Hirano ${ }^{2}$ and Takuya Watanabe ${ }^{1, * \text { (D) }}$ \\ 1 Laboratory of Cardiovascular Medicine, Tokyo University of Pharmacy and Life Sciences, \\ Tokyo 192-0392, Japan; ksato@toyaku.ac.jp (K.S.); s106101@toyaku.ac.jp (R.S.); s139110@toyaku.ac.jp (M.Y.); \\ s126208@toyaku.ac.jp (T.Y.); s149064@toyaku.ac.jp (K.S.); s149021@toyaku.ac.jp (T.O.) \\ 2 Department of Medicine, Division of Diabetes, Metabolism, and Endocrinology, Showa University School of \\ Medicine, Tokyo 142-8666, Japan; torigoe1234@yahoo.co.jp (Y.M.); hirano@med.showa-u.ac.jp (T.H.) \\ 3 Department of Legal Medicine, Showa University School of Medicine, Tokyo 142-8555, Japan; \\ taka94242879@gmail.com \\ 4 Department of Pathology, National Cerebral and Cardiovascular Center, Osaka 565-8565, Japan; \\ hueda@ncvc.go.jp \\ * Correspondence: watanabe@toyaku.ac.jp; Tel.: +81-42-676-6983; Fax: +81-42-676-5084
}

Received: 25 April 2018; Accepted: 6 June 2018; Published: 11 June 2018

\begin{abstract}
Vaspin (visceral adipose tissue-derived serine protease inhibitor) was recently identified as a novel adipocytokine with insulin-sensitizing effects. Serum vaspin levels are reported either increased or decreased in patients with coronary artery disease. Our translational research was performed to evaluate the expression of vaspin in human coronary atherosclerotic lesions, and its effects on atherogenic responses in human macrophages and human aortic smooth muscle cells (HASMC), as well as aortic atherosclerotic lesion development in spontaneously hyperlipidemic $A_{p o e^{-/-}}$mice, an animal model of atherosclerosis. Vaspin was expressed at high levels in macrophages/vascular smooth muscle cells (VSMCs) within human coronary atheromatous plaques. Vaspin significantly suppressed inflammatory phenotypes with nuclear factor $\mathrm{kB}$ down-regulation in human macrophages. Vaspin significantly suppressed oxidized low-density lipoprotein-induced foam cell formation with CD36 and acyl-coenzyme A: cholesterol acyltransferase-1 down-regulation and ATP-binding cassette transporters A1 and G1, and scavenger receptor class B type 1 up-regulation in human macrophages. Vaspin significantly suppressed angiotensin II-induced migration and proliferation with ERK1/2 and JNK down-regulation, and increased collagen production with phosphoinositide 3-kinase and Akt up-regulation in HASMCs. Chronic infusion of vaspin into Apoe ${ }^{-/-}$mice significantly suppressed the development of aortic atherosclerotic lesions, with significant reductions of intraplaque inflammation and the macrophage/VSMC ratio, a marker of plaque instability. Our study indicates that vaspin prevents atherosclerotic plaque formation and instability, and may serve as a novel therapeutic target in atherosclerotic cardiovascular diseases.
\end{abstract}

Keywords: vaspin; atherosclerosis; macrophage; vascular smooth muscle cell; $A p o e^{-/-}$mice

\section{Introduction}

Atherosclerosis is a chronic inflammatory disease arising from endothelial injury and accumulation of cholesterol-laden macrophage foam cells in the artery wall [1]. Macrophages play a key role in vascular inflammation by changing phenotype of pro-inflammatory (M1) or anti-inflammatory (M2) [2]. 
Macrophage foam cell formation is characterized by cholesterol ester accumulation that depends on the homeostatic balance among the uptake of oxidized low-density lipoprotein (LDL) via a scavenger receptor CD36, the efflux of free cholesterol controlled by ATP-binding cassette transporters A1 and G1 (ABCA1, ABCG1) and scavenger receptor class B type 1 (SRB1), and cholesterol esterification from excess free cholesterol by acyl-coenzyme A: cholesterol acyltransferase 1 (ACAT1) [3]. Cholesterol ester stored in lipid droplets can be removed from cells only after hydrolysis, to free cholesterol by neutral cholesterol ester hydrolase (NCEH) [4]. Vascular smooth muscle cells (VSMCs) contribute to the formation of atheromatous plaque by their migration, proliferation, and production of extracellular matrix (ECM) components, such as collagen, matrix metalloproteinase (MMP), fibronectin, and elastin [5]. In addition to plaque size, plaque phenotype is also important in evaluating plaque rupture [6].

Vaspin (visceral adipose tissue-derived serine protease inhibitor) was identified as a $45.2-\mathrm{kDa}$ adipocytokine secreted from visceral adipose tissues of Otsuka Long-Evans Tokushima fatty rats, an animal model of type 2 diabetes with obesity [7]. Human vaspin belongs to serpin family A member 12 (serpin A12), which is coded by SERPINA12. Human vaspin precursor protein contains 414 amino acids that include the 395 amino acid peptide hormone and a 19 amino acid signal peptide. Human and mouse vaspin share about $81 \%$ amino acid sequence of reactive site loop identity ( $\sim 62 \%$ identity in full-length), and exhibit cross-species activity [7]. Vaspin is expressed in visceral and subcutaneous adipose tissues, peripheral blood mononuclear cells, macrophage foam cells, and VSMCs [8-11]. The receptors for vaspin are still not elucidated. Vaspin is known to effect glucose-insulin homeostasis, appetite regulation, bone metabolism, and vascular health [7,12-14].

Vaspin inhibits the generation of reactive oxygen species (ROS) and the expression of pro-inflammatory molecules, such as interleukin 1 , monocyte chemotactic protein 1 , vascular cell adhesion molecule 1, intercellular adhesion molecule 1, and selectin $E$ in human vascular endothelial cells (ECs), and monocyte-EC adhesion [15-17]. Vaspin inhibits platelet-derived growth factor BB-induced migration and high glucose-induced proliferation in rat VSMCs $[18,19]$. Vaspin enhances cholesterol efflux by ABCA1 up-regulation in THP1 monocyte-derived macrophages [20]. Administration and overexpression of vaspin ameliorates glucose tolerance, insulin sensitivity, atherosclerosis, and neointimal hyperplasia of balloon-injured carotid arteries in murine [7,21-23]. Several lines of clinical evidence have shown that blood vaspin levels are elevated in patients with obesity, diabetes, metabolic syndrome, and coronary artery disease (CAD) [24-27]. In contrast, other studies have shown that blood vaspin levels are decreased in the presence and severity of CAD [11,28-31].

In the present study, we assessed the expression levels of vaspin in human coronary artery lesions in CAD patients, and the anti-atherogenic effects of vaspin on the inflammatory phenotype and foam cell formation in human macrophages, as well as the migration, proliferation, and ECM production in human aortic smooth muscle cells (HASMCs) in vitro. In addition, in vivo experiments focused on the inhibitory effects of vaspin against the development of aortic atherosclerotic lesions and plaque instability in spontaneously hyperlipidemic $A p o e^{-/-}$mice, an animal model of atherosclerosis. This study was performed as translational research, i.e., it is an attempt to study a candidate therapeutic target for atherosclerosis.

\section{Results}

\subsection{Expression of Vaspin in Human Coronary Atherosclerosis}

The expression of vaspin was not observed in human normal coronary arteries (Figure 1A). However, vaspin was expressed at high levels in atheromatous plaques (macrophage foam cells) and thick media (VSMCs) in human coronary arteries (Figure 1B). 


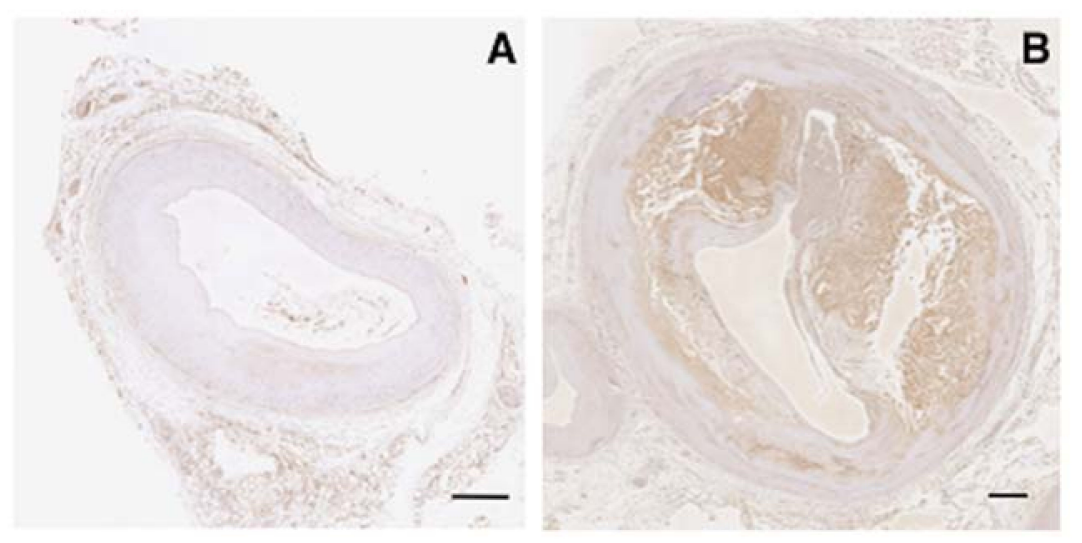

Figure 1. Immunohistological expression of vaspin in human coronary arteries from a non-CAD patient (male, 39 years old, dilated cardiomyopathy; (A)) and a CAD patient (male, 80 years old, acute myocardial infarction; (B)). Bar $=500 \mu \mathrm{m}$.

\subsection{Expression of Vaspin in Human Vascular Cells}

SERPINA12 and vaspin was abundantly expressed in THP1 monocytes, their derived macrophages, HASMCs, human umbilical vein endothelial cells (HUVECs), and human aortic endothelial cells (HAECs) at mRNA and protein expression levels (Figure 2A).

A

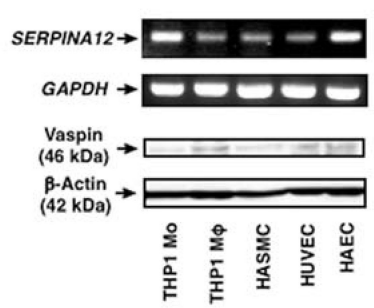

B $\quad \operatorname{CD68}$

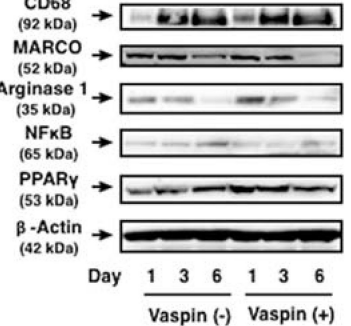

C
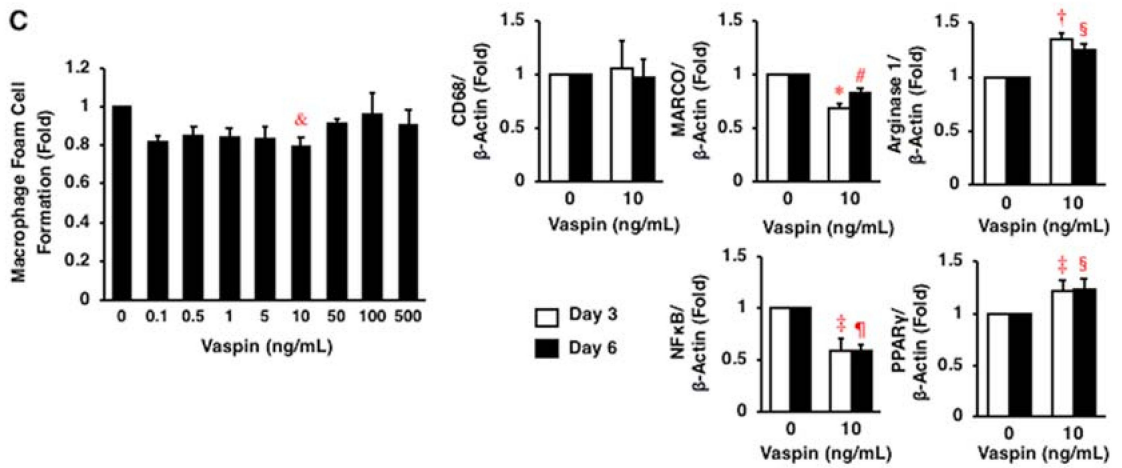

Figure 2. Expression of vaspin and its effects on inflammatory phenotype and foam cell formation in human macrophages. (A) Expression of SERPINA12 and vaspin in human vascular cells, such as THP1 monocytes, their derived macrophages, HASMCs, HUVECs, and HAECs was assessed by RT-PCR and immunoblotting. GAPDH and $\beta$-actin served as loading controls. (B) Effects of vaspin on inflammatory phenotypes in THP1 monocyte-derived macrophages were assessed by immunoblotting $(n=3-4)$. ${ }^{*} p<0.0005,{ }^{\dagger} p<0.005,{ }^{\ddagger} p<0.05$ vs. control on day $3{ }^{*}{ }^{\#} p<0.005,{ }^{\S} p<0.05,{ }^{\text {Il }} p<0.0005$ vs. control on day 6. (C) Effects of vaspin on oxidized LDL-induced foam cell formation in THP1 monocyte-derived macrophages were assessed by cholesterol esterification assay $(n=5) .1 \mathrm{fold}=5.72 \pm 0.65 \mathrm{nmol} / \mathrm{mg}$ cell protein. \& $p<0.05$ vs. $0 \mathrm{ng} / \mathrm{mL}$ of vaspin. 


\subsection{Effects of Vaspin on Inflammatory Phenotype in Human Monocytes/Macrophages}

After 1-6 days of culture, the differentiation of THP1 monocytes into macrophages was confirmed by increased expression of CD68, a macrophage differentiation marker (Figure 2B). Vaspin $(10 \mathrm{ng} / \mathrm{mL}$ ) did not affect monocyte differentiation into macrophages. However, vaspin $(10 \mathrm{ng} / \mathrm{mL})$ significantly decreased the expression of MARCO, an M1 marker, and increased arginase 1, an M2 marker, through differentiation ( $p<0.05$ to $p<0.0005$; Figure 2B). These observations indicated that vaspin shifted the macrophage phenotype overwhelmingly to M2 rather than M1, which was associated with significant changes of nuclear factor $\mathrm{KB}(\mathrm{NF} \kappa \mathrm{B})$ down-regulation and peroxisome proliferator-activated receptor $\gamma(\operatorname{PPAR} \gamma)$ up-regulation $(p<0.05$ to $p<0.0005$; Figure 2B).

\subsection{Effects of Vaspin on Human Macrophage Foam Cell Formation}

Vaspin suppressed oxidized LDL-induced foam cell formation by $20 \%$ at $10 \mathrm{ng} / \mathrm{mL}$ in THP1 monocyte-derived macrophages $(p<0.05$; Figure 2C). Vaspin at 100 and $500 \mathrm{ng} / \mathrm{mL}$ suppressed the protein expression of CD36 and ACAT1 by $20 \%$ and 30\%, respectively $(p<0.0001, p<0.05$; Figure 3A,B), but not NCEH ( $p>0.05$; Figure 3C). Vaspin enhanced the protein expression of ABCA1, ABCG1, and SRB1 by 1.5-2.0 fold at 10-500 ng/mL ( $p<0.05$ to $p<0.0001$; Figure 3D-F).
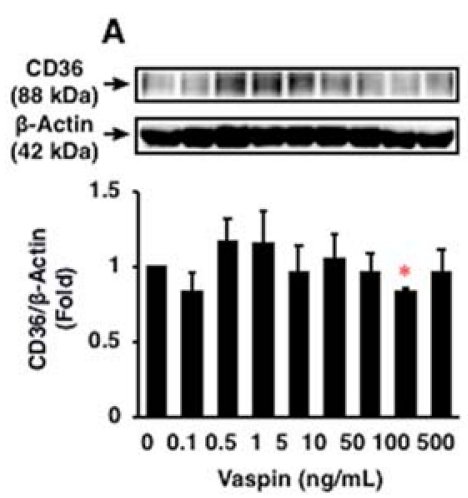

D

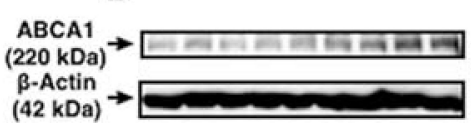

(42 kDa)

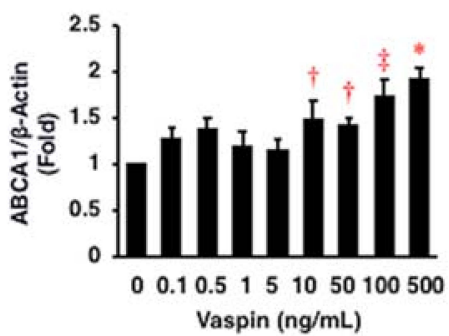

B
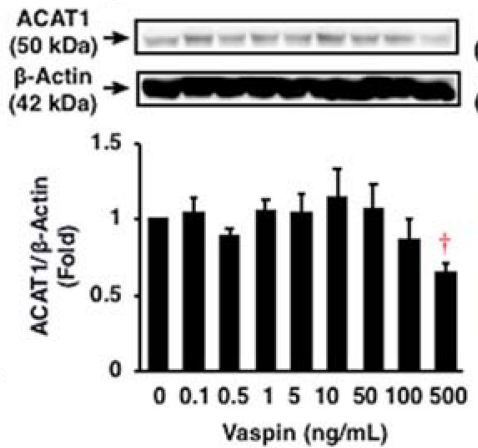

$\mathrm{E}$

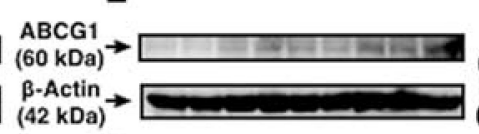

$(42 \mathrm{kDa})$

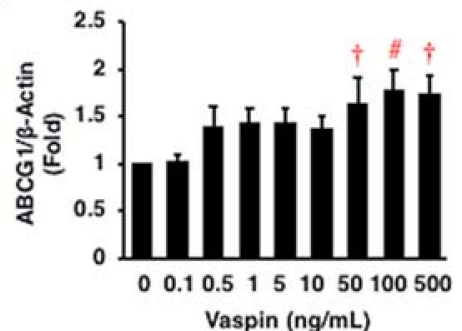

C

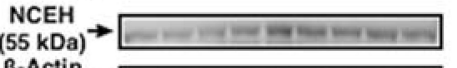

B-Actin

$(42 \mathrm{kDa})$

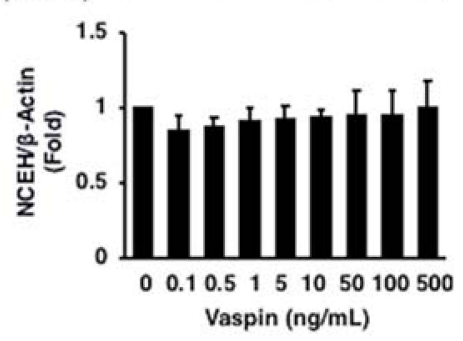

$\mathbf{F}$

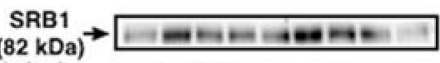

-Actin
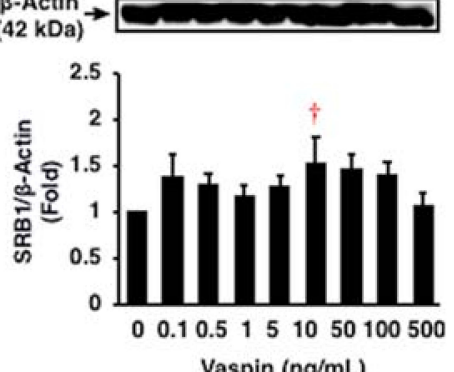

Figure 3. Effects of vaspin on foam cell formation related protein expression in THP1 monocyte-derived macrophages were assessed by immunoblotting. The blotted membranes were cut for reacting with different antibodies, and the blots were stripped and reprobed in the same membrane. Top: Representative results of protein expression of each CD36 (A), ACAT1 (B), NCEH (C), ABCA1 (D), ABCG1 (E), and SRB1 (F). Bottom: Densitometric data of each molecule after normalization relative to $\beta$-actin $(n=5-6) .{ }^{*} p<0.0001,{ }^{\dagger} p<0.05,{ }^{\ddagger} p<0.001,{ }^{\#} p<0.01 \mathrm{vs.} 0 \mathrm{ng} / \mathrm{mL}$ of vaspin.

\subsection{Effects of Vaspin on Migration and Proliferation of HASMCs}

Angiotensin II $(500 \mathrm{nmol} / \mathrm{L})$ significantly increased the migration of HASMCs $(p<0.005$; Figure 4A). Vaspin $(500,2000 \mathrm{ng} / \mathrm{mL})$ significantly suppressed the angiotensin II-induced migration of HASMCs (both $p<0.0001$; Figure 4A). Vaspin $(100-2000 \mathrm{ng} / \mathrm{mL})$ significantly suppressed the 
proliferation of HASMCs ( $p<0.05$ to $p<0.0001$; Figure 4B). However, vaspin $(500,2000 \mathrm{ng} / \mathrm{mL})$ did not affect significantly apoptosis in HASMCs (Figure 4C).

A

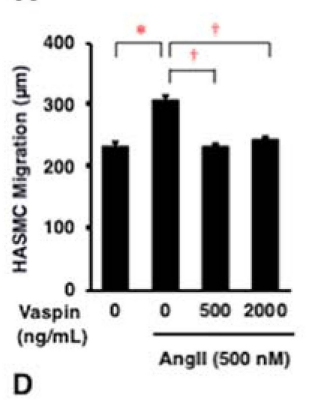

B

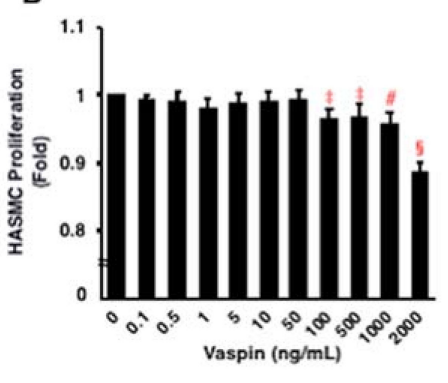

$\mathrm{c}$
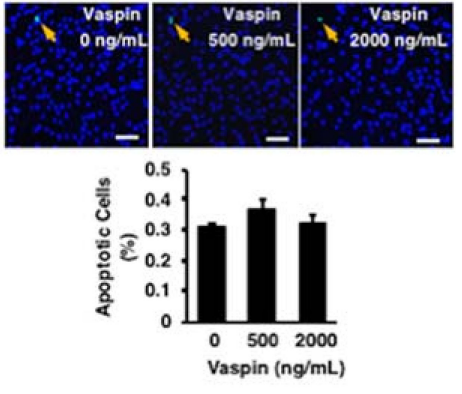
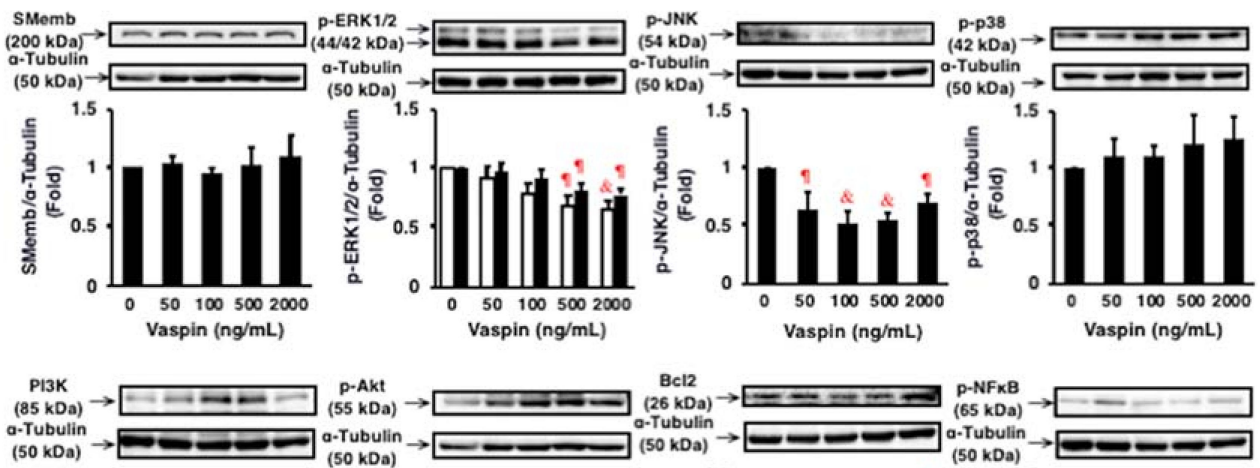

$\mathrm{Bc12} \rightarrow+\mathrm{P}-\mathrm{NFKB}$
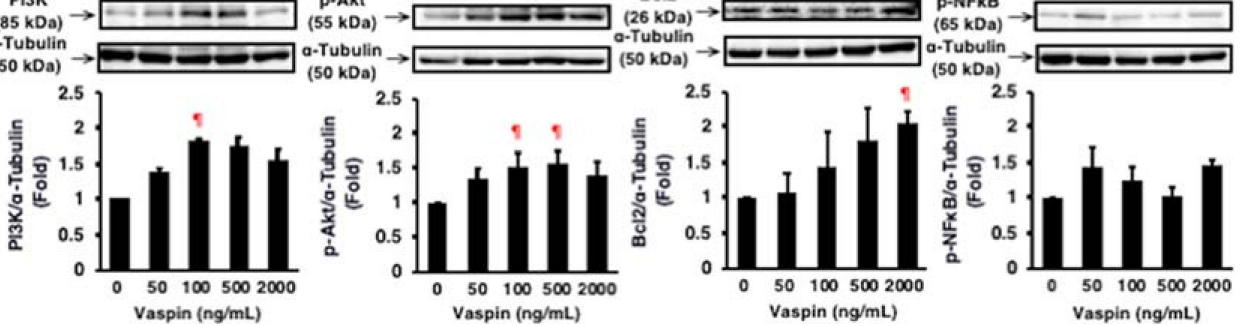

Figure 4. Effects of vaspin on migration, proliferation, apoptosis, and intracellular signal transductions in HASMCs. (A) Effect of vaspin on angiotensin II (Ang II)-induced migration was determined in 10 cells per well using a BIOREVO BZ-9000 microscope. The experiments were repeated independently 4 times. ${ }^{*} p<0.005,{ }^{\dagger} p<0.0001$. (B) Effect of vaspin on proliferation was determined by WST- 8 assay $(n=4) .{ }^{\ddagger} p<0.05,{ }^{\#} p<0.001, \S p<0.0001 \mathrm{vs.} 0 \mathrm{ng} / \mathrm{mL}$ of vapin. (C) Effect of vaspin on apoptosis was evaluated by detecting apoptotic cells (green) using the TUNEL method. Nuclei were co-stained with 6-diamidino-2-phenylindole (blue). The graph indicates the percentage of apoptotic cells in 3 independent experiments. Bar $=100 \mu \mathrm{m}$. (D) Relevant intracellular signals in response to vaspin were assessed by immunoblotting. The blotted membranes were cut for reacting with different antibodies, and the blots were stripped and reprobed in the same membrane. Top: Representative results of protein expression/phosphorylation of SMemb, ERK1/2, JNK, p38, PI3K, Akt, Bcl2, and NFkB. Bottom: Densitometric data of each molecule after normalization relative to $\alpha$-tubulin $(n=4-5)$. ${ }^{\mathbb{I}} p<0.05$, $\& p<0.01 \mathrm{vs.} 0 \mathrm{ng} / \mathrm{mL}$ of vapin (corresponding control).

\subsection{Effects of Vaspin on Intracellular Signaling in HASMCs}

Vaspin significantly suppressed ERK1/2 and JNK phosphorylation, but increased phosphoinositide 3-kinase (PI3K) and Bcl2 expression and Akt phosphorylation in HASMCs $(p<0.05$ to $p<0.01$; Figure 4D). Vaspin did not significantly alter the expression of SMemb, a proliferative marker, and p38 and NFKB phosphorylation in HASMCs ( $p>0.05$; Figure 4D). 


\subsection{Effects of Vaspin on ECM Expression in HASMCs}

Vaspin significantly increased protein expression of collagen 1 and collagen 3 in HASMCs (both $p<0.05$; Figure 5A,B). However, vaspin had no significant effects on protein expression of fibronectin, elastin, and MMP2 in HASMCs ( $p>0.05$; Figure 5C-E).
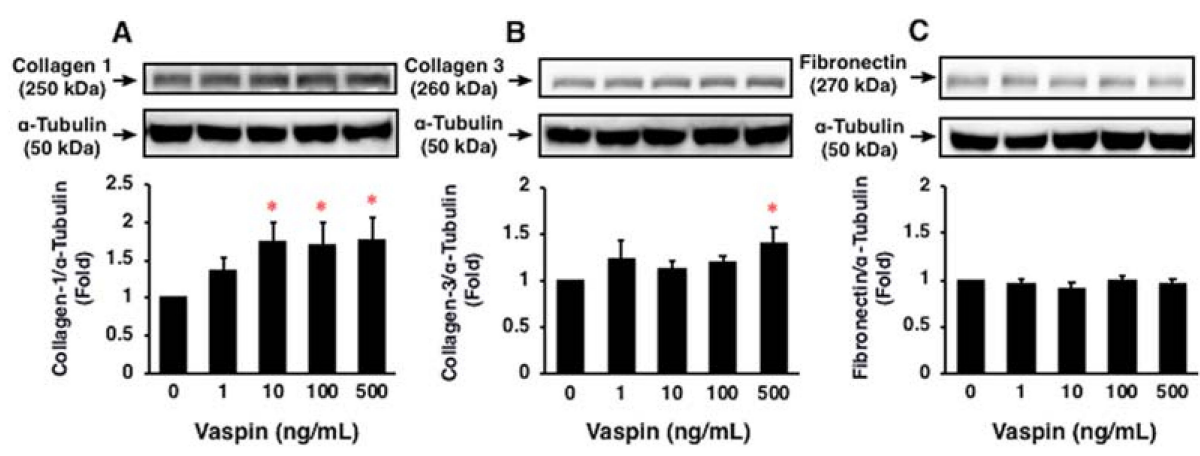

D

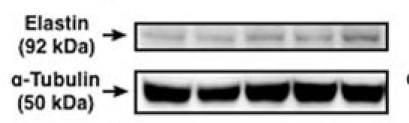

$E$
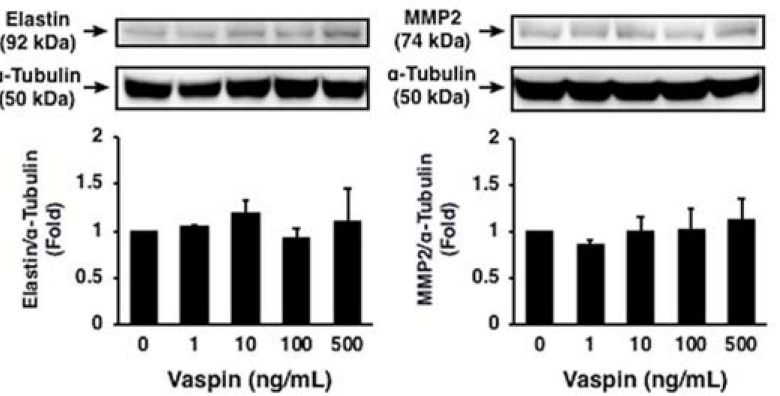

Figure 5. Effects of vaspin on ECM expression in HASMCs were assessed by immunoblotting. The blottted membranes were cut for reacting with different antibodies, and the blots were stripped and reprobed in the same membrane. Top: Representative results of protein expression of collagen 1 (A), collagen 3 (B), fibronectin (C), elastin (D), and MMP2 (E). Bottom: Densitometric data of each molecule after normalization relative to $\alpha$-tubulin $(n=3-4)$. ${ }^{*} p<0.05$ vs. $0 \mathrm{ng} / \mathrm{mL}$ of vaspin.

\subsection{Effects of Vaspin on Atherosclerotic Lesion Development in Apoe ${ }^{-/-}$Mice}

Body weight significantly increased with age (17 to 21 weeks old), but did not differ significantly among 21-week-old Apoe $\mathrm{e}^{-/-}$mice infused with 3 doses of vaspin (Table 1). There were no significant differences in food intake, systolic and diastolic blood pressures, or plasma levels of total cholesterol, high-density lipoprotein (HDL) cholesterol, and non-HDL cholesterol among four groups of Apoe ${ }^{-/-}$ mice (Table 1). High-dose of vaspin significantly decreased free fatty acid level and tended to decrease fasting glucose and triglyceride levels and homeostasis model assessment of insulin resistance (HOMA-IR) in Apoe $e^{-/-}$mice (Table 1). Low-dose of vaspin significantly increased both plasma insulin level and HOMA-IR in Apoe ${ }^{-/-}$mice (Table 1).

Both the entire atherosclerotic lesions in aortic lumen surface and plaque size of aortic sinus wall significantly increased with age in Apoe $e^{-/-}$mice $(p<0.0001, p<0.001$; Figure $6 \mathrm{~A}(\mathrm{a}, \mathrm{b}, \mathrm{e}, \mathrm{f}), \mathrm{B}, \mathrm{C})$. These were accompanied with significant increases in monocyte-macrophage infiltration, VSMC content, vascular inflammation (pentraxin 3), and the ratio of monocyte-macrophage content/VSMC content in atheromatous plaques $(p<0.05$ to $p<0.0001$; Figure $6 \mathrm{~A}(\mathrm{i}, \mathrm{j}, \mathrm{m}, \mathrm{n}, \mathrm{q}, \mathrm{r}), \mathrm{D}-\mathrm{G})$. However, 4-week infusion of high-dose vaspin significantly decreased the entire atherosclerotic lesions in aortic lumen surface and plaque size of aortic sinus wall $(p<0.005, p<0.05$; Figure $6 \mathrm{~A}(\mathrm{~b}, \mathrm{~d}, \mathrm{f}, \mathrm{h}), \mathrm{B}, \mathrm{C})$. Vaspin infusion at high dose or both doses significantly decreased monocyte-macrophage infiltration, VSMC content, pentraxin 3 expression, and the ratio of monocyte-macrophage content/VSMC 
content, a biomarker of plaque instability, in atheromatous plaques $(p<0.05$ to $p<0.01$; Figure $6 \mathrm{~A}(\mathrm{j}-1, \mathrm{n}-\mathrm{p}, \mathrm{r}-\mathrm{t}), \mathrm{D}-\mathrm{G})$.

Table 1. Characteristics and laboratory data of $A p o e^{-/-}$mice.

\begin{tabular}{|c|c|c|c|c|}
\hline \multirow[b]{2}{*}{ Parameter } & \multirow{2}{*}{$\begin{array}{c}17 \text { Weeks Old } \\
\text { Before }\end{array}$} & \multicolumn{3}{|c|}{21 Weeks Old } \\
\hline & & $\begin{array}{c}\text { Vaspin } \\
0 \mu \mathrm{g} / \mathrm{kg} / \mathrm{h}\end{array}$ & $\begin{array}{l}\text { Vaspin } \\
2.5 \mu \mathrm{g} / \mathrm{kg} / \mathrm{h}\end{array}$ & $\begin{array}{c}\text { Vaspin } \\
5.0 \mu \mathrm{g} / \mathrm{kg} / \mathrm{h}\end{array}$ \\
\hline$N$ & 7 & 7 & 5 & 6 \\
\hline Body weight (g) & $26.2 \pm 0.6$ & $28.4 \pm 0.5^{*}$ & $28.7 \pm 0.3^{*}$ & $28.7 \pm 0.9^{*}$ \\
\hline Food intake (g/day) & $4.0 \pm 0.4$ & $4.1 \pm 0.1$ & $4.3 \pm 0.1$ & $4.1 \pm 0.1$ \\
\hline Systolic blood pressure ( $\mathrm{mm} \mathrm{Hg}$ ) & $93.3 \pm 1.6$ & $92.1 \pm 1.2$ & $89.5 \pm 0.2$ & $91.6 \pm 2.5$ \\
\hline Diastolic blood pressure ( $\mathrm{mm} \mathrm{Hg}$ ) & $70.3 \pm 1.2$ & $71.2 \pm 1.6$ & $68.4 \pm 0.9$ & $70.4 \pm 2.5$ \\
\hline Total cholesterol (mg/dL) & $2282.3 \pm 167.8$ & $2209.7 \pm 126.5$ & $2036.8 \pm 119.0$ & $2176.5 \pm 44.6$ \\
\hline Non-HDL cholesterol (mg/dL) & $2269.9 \pm 168.5$ & $2198.0 \pm 125.2$ & $2030.6 \pm 118.2$ & $2168.3 \pm 44.8$ \\
\hline HDL cholesterol $(\mathrm{mg} / \mathrm{dL})$ & $12.5 \pm 2.5$ & $11.7 \pm 4.5$ & $6.3 \pm 2.0$ & $8.2 \pm 1.0$ \\
\hline Triglyceride (mg/dL) & $287.0 \pm 48.8$ & $283.4 \pm 38.4$ & $270.8 \pm 48.5$ & $174.3 \pm 40.7$ \\
\hline Free fatty acid (mEq/L) & $4.1 \pm 0.7$ & $2.7 \pm 0.8$ & $2.2 \pm 0.5$ & $1.0 \pm 0.2^{\dagger}$ \\
\hline Glucose $(\mathrm{mg} / \mathrm{dL})$ & $295.4 \pm 49.0$ & $259.3 \pm 31.3$ & $281.3 \pm 18.9$ & $172.9 \pm 32.3$ \\
\hline Insulin ( $\mathrm{pmol} / \mathrm{L})$ & $24.5 \pm 7.4$ & $26.2 \pm 6.6$ & $65.4 \pm 16.4^{\ddagger}$ & $26.6 \pm 10.4$ \\
\hline HOMA-IR & $2.3 \pm 0.6$ & $3.5 \pm 1.1$ & $6.6 \pm 1.8^{+}$ & $1.8 \pm 0.8$ \\
\hline
\end{tabular}

Measurements of body weight, food intake, systolic and diastolic blood pressures, fasting plasma parameters were performed before (17 weeks old) and after 4-week infusion of 3 dosing rates of vaspin (21 weeks old) in Apoe $e^{-/-}$ mice. ${ }^{*} p<0.05,{ }^{\dagger} p<0.005$ vs. 17 weeks old; ${ }^{\ddagger} p<0.05$ vs. others.

\section{A}

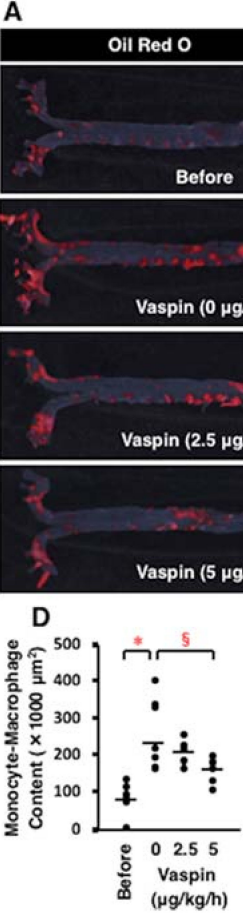

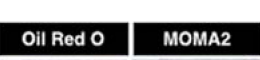
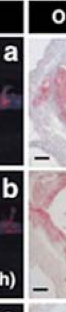

$E$
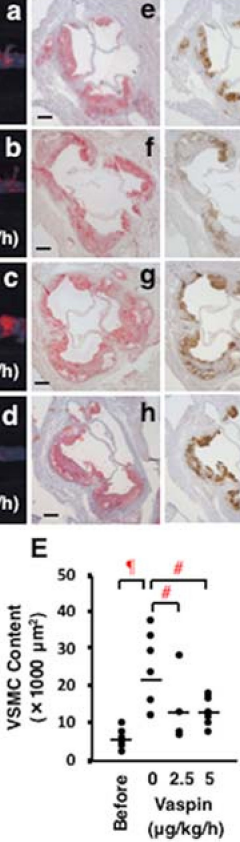

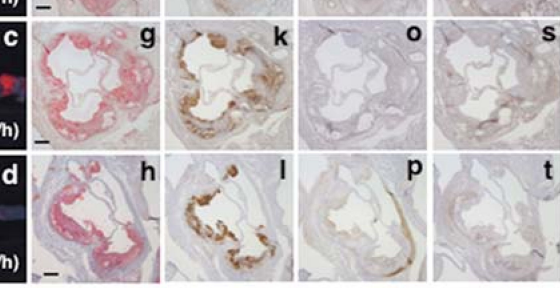

a-SMA
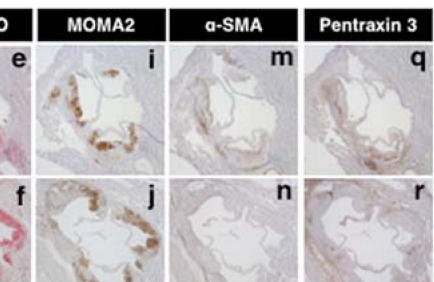

$\mathbf{F}$

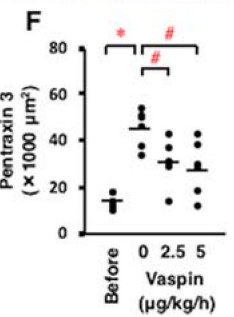

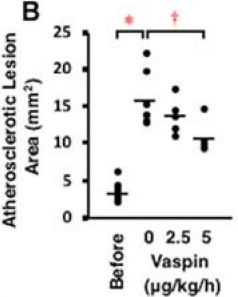

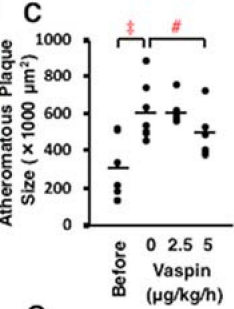

G

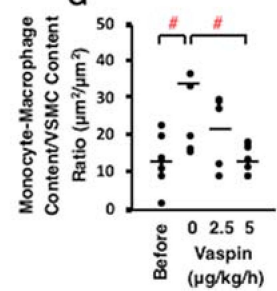

Figure 6. Effects of vaspin on atherosclerotic lesion development in $A p o e^{-/-}$mice. Seven mice were sacrificed before infusion (17 weeks old), and 7, 5, and 6 mice were sacrificed after a 4-week continuous subcutaneous infusion of 3 dosing rates of vaspin $(0,2.5,5 \mu \mathrm{g} / \mathrm{kg} / \mathrm{h}$ ), respectively. (A) Atherosclerotic lesions were stained with Oil Red $\mathrm{O}$ on the aortic surface (a-d). Cross-sections of the aortic sinus were stained with Oil Red O (e-h), MOMA2 for monocytes/macrophages (i-1), $\alpha$-SMA for VSMCs $(\mathbf{m}-\mathbf{p})$, or pentraxin 3 for vascular inflammation $(\mathbf{q}-\mathbf{t})$. Hematoxylin was used for nuclear staining. Bar $=200 \mu \mathrm{m}$. (B-G) Comparisons of these positive area and the ratio of monocyte-macrophage content/VSMC content within atheromatous plaques were performed among 4 groups. Bars indicate the mean values in the graphs. ${ }^{*} p<0.0001,{ }^{\dagger} p<0.005,{ }^{\ddagger} p<0.001,{ }^{\#} p<0.05,{ }^{\S} p<0.01$, II $p<0.0005$. 


\section{Discussion}

The present study provides comprehensive evidence that vaspin inhibits atherogenesis by suppressing the inflammatory phenotype and foam cell formation in macrophages, as well as the migration and proliferation of VSMCs (Figure 7). Vaspin also contributes to stabilizing plaque by increasing collagens and reducing the macrophage/VSMC ratio in atheromatous plaques (Figure 7). Other studies have shown that vaspin inhibits the expression of pro-inflammatory molecules in ECs and monocyte-EC adhesion $[16,17]$. Lin et al. have shown that vaspin attenuates atherogenesis by inhibiting endoplasmic reticulum (ER) stress-induced macrophage apoptosis in Apoe ${ }^{-/-}$mice [22].

Vaspin transgenic mice prevented diet-induced obesity, glucose intolerance, and hepatic steatosis, while vaspin-deficient mice developed glucose intolerance associated with up-regulation of ER stress markers [21]. Vaspin improved ER stress and insulin resistance in obese mice by acting as a ligand for cell-surface glucose regulated protein 78/murine tumor cell DnaJ-like protein 1 complex via p-Akt in the liver [21]. Adenovirus vector carrying the full length of the vaspin suppressed neointimal hyperplasia of balloon-injured carotid arteries in streptozotocin-induced diabetic Wistar rats [23]. The intimal proliferation was also suppressed in cuff-injured femoral arteries in vaspin transgenic mice [23].

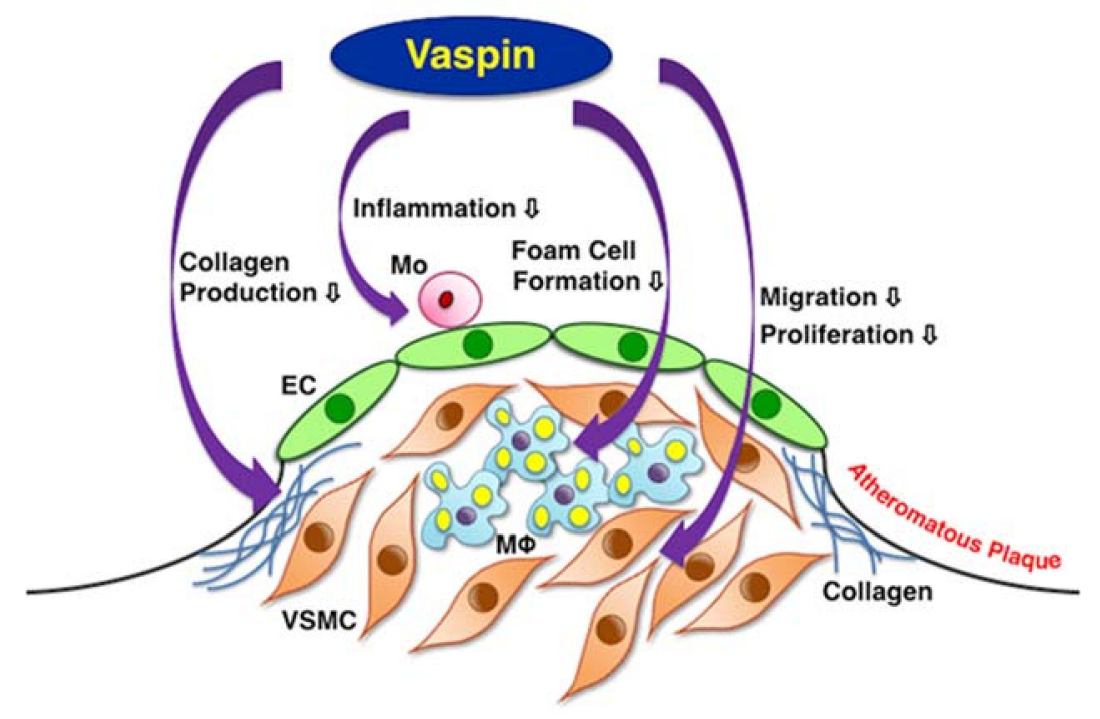

Figure 7. Schema of multiple anti-atherogenic effects of vaspin. EC = endothelial cell, Mo = monocyte, $\mathrm{M} \varphi=$ macrophage, VSMC = vascular smooth muscle cell.

Several studies have shown that vaspin increases insulin secretion and ameliorates insulin resistance [7,32]. Vaspin also inhibits kallikrein 7-mediated insulin degradation by a classical serpin mechanism [33]. The present study showed that chronic infusion of high-dosing rate of vaspin $(5 \mu \mathrm{g} / \mathrm{kg} / \mathrm{h})$ improved insulin resistance and decreased fasting plasma glucose level in Apoe $e^{-/-}$ mice. However, chronic infusion of low-dosing rate of vaspin $(2.5 \mu \mathrm{g} / \mathrm{kg} / \mathrm{h})$ did not improve insulin resistance with increased fasting plasma glucose and insulin levels in $A p o e^{-/-}$mice. We speculate that the reason for this is as follows: vaspin infusion into $\mathrm{Apoe}^{-/-}$mice may start to stimulate insulin secretin from pancreas at low doses and accelerate to ameliorate insulin sensitivity in skeletal muscle, fat, and liver in dose-dependent manner. Further studies, such as glucose/insulin tolerance test, are needed to clarify the precise mechanism.

Previous studies have shown that vaspin protects blood vessels by suppressing ROS generation and inflammation via down-regulating the NFKB pathway, and by inhibiting apoptosis via up-regulating the PI3K-Akt-endothelial nitric oxide synthase pathway in ECs [15,33-35]. In the present study, vaspin decreases M1 phenotype acquisition and increases the expression of the M2 phenotype associated with $\mathrm{NF} \kappa \mathrm{B}$ down-regulation and PPAR $\gamma$ up-regulation in monocyte-derived macrophages. 
Vaspin suppresses foam cell formation associated with CD36 and ACAT1 down-regulation, as well as ABCA1, ABCG1, and SRB1 up-regulation in macrophages. Vaspin suppresses the migration and proliferation via the down-regulation of ERK1/2 and JNK pathways, and increases collagen production via the up-regulation of the PI3K-Akt pathway in VSMCs. It is possible that vaspin may not induce apoptosis via activating the PI3K-Akt-Bcl2 pathway in VSMCs.

We discuss the integrity of vaspin levels in our experiments. Several studies have shown that plasma concentrations of vaspin are $\sim 2.18 \mathrm{ng} / \mathrm{mL}$ in healthy subjects and $\sim 0.47 \mathrm{ng} / \mathrm{mL}$ in CAD patients [29]. The concentrations of vaspin required for modulation of several responses of THP1 monocyte-derived macrophages and HASMCs were 10-2000 ng/mL in our study, and were $100-150 \mathrm{ng} / \mathrm{mL}$ for macrophage and EC responses in other studies $[17,20,36]$. According to our previous studies [37-39], atheroprotective agents are increased to counteract the development of atherosclerosis. The local levels of vasoactive agents could increase to a similar degree by the generation from vascular cells in an autocrine/paracrine fashion [40,41]. Our study shows that the expression of vaspin is increased in macrophages and VSMCs within coronary atherosclerotic lesions. However, decreased circulating blood levels of vaspin in CAD patients may be attributed to severe endothelial dysfunction due to CAD. In monocyte-derived macrophages, the adequate concentrations of vaspin differed in inducing foam cell formation and related protein expression $(10-500 \mathrm{ng} / \mathrm{mL})$. This is mostly dependent on the difference in the presence or absence of oxidized LDL. Vaspin at higher than adequate concentrations might lead to the down-regulation of the receptor and intracellular signals. The adequate concentrations of vaspin also differ between macrophages and VSMCs.

Several clinical studies have shown that circulating blood levels of vaspin are significantly increased to improve insulin resistance in patients with type 2 diabetes and metabolic syndrome [24-26], but decreased due to severe endothelial dysfunction in patients with CAD $[11,29,30]$. In patients with type 2 diabetes, vaspin levels are decreased by improvement in insulin resistance with exercise and metformin in men and women, respectively [42,43]. Vaspin levels are increased by rosuvastatin in obese patients with CAD [44]. This is attributed to the improvement effect of rosuvastatin on endothelial dysfunction in CAD patients [45].

In conclusion, the results from the present study indicate that vaspin inhibits atherogenesis by suppressing vascular inflammation, macrophage foam cell formation, and VSMC migration and proliferation. Vaspin also contributes to stabilizing plaque by increasing collagens and reducing the intraplaque macrophage/VSMC ratio. Targeting vaspin allows us to open a therapeutic window for combating atherosclerosis and related diseases, as well as for maintaining vascular health.

\section{Materials and Methods}

\subsection{Materials}

Recombinant human vaspin produced in E. coli was purchased from PeproTech (Rocky Hill, NJ, USA) for in vitro experiments and GenScript (Piscataway, NJ, USA) for in vivo experiments; the purity was $\geq 98 \%$ and $>95 \%$, respectively. Rabbit polyclonal anti-human vaspin antibody was purchased from GeneTex (Irvine, CA, USA). Angiotensin II was purchased from Sigma (St. Louis, MO, USA), and phorbol 12-myristate 13-acetate was from Wako (Osaka, Japan). HUVECs and HASMCs were purchased from Lonza (Walkersville, MD, USA) and THP1 monocytes were from Health Science Research Resources Bank (Osaka, Japan).

\subsection{Human Coronary Artery Immunostaining}

This study was deemed exempt as retrospective autopsied coronary artery specimens by the National Cerebral and Cardiovascular Center Review Board (M18-020, 27 July 2006). Written informed consent to autopsy was obtained from families. Buffered $10 \%$ formalin-fixed paraffin-embedded human coronary artery specimens from archive autopsy collections of the National Cerebral and Cardiovascular Center were used for immunohistochemistry. Serial cross-sections of coronary arteries 
from four male patients with CAD (aged 71-87) and three male patients with dilated cardiomyopathy (as non-CAD examples) (aged 19-39) were stained with rabbit polyclonal anti-human vaspin antibody. Immunodetection (as a secondary antibody) was performed with the Bond Polymer Refine Detection kit (Leica Biosystems, Newcastle, UK) [37].

\subsection{Migration Assay}

HASMCs were seeded onto 8-well culture slide $\left(3 \times 10^{3}\right.$ cells $/ 200 \mu \mathrm{L} /$ well $)$. Cells were incubated at $37^{\circ} \mathrm{C}$ in $5 \% \mathrm{CO}_{2}$ for $3-5 \mathrm{~h}$ in SmGM-2, and then incubated for $24 \mathrm{~h}$ in serum-free SmGM-2 for starvation. Subsequently, while cells were incubated for $16 \mathrm{~h}$ in serum-free SmBM with $500 \mathrm{nmol} / \mathrm{L}$ angiotensin II and the indicated concentrations of vaspin, photographs of cells were taken for the last $5 \mathrm{~h}$ at 10-min intervals. The average migration distance of 10 cells randomly selected in each well was measured using a BIOREVO BZ-9000 microscope (Keyence, Osaka, Japan) [37-39,46-50].

\subsection{Proliferation Assay}

HASMCs were seeded onto 96-well plates $\left(1 \times 10^{4}\right.$ cells $/ 100 \mu \mathrm{L} /$ well $)$ and incubated at $37^{\circ} \mathrm{C}$ in $5 \% \mathrm{CO}_{2}$ for $24 \mathrm{~h}$ in SmGM-2 (Lonza). Cells were further incubated for $48 \mathrm{~h}$ with the indicated concentrations of vaspin with renewal of each medium. Then, $10 \mu \mathrm{L}$ of WST-8 solution (Cell Count Reagent SF; Nacalai Tesque, Kyoto, Japan) was added to each well [37-39,46-50]. After $1 \mathrm{~h}$ of incubation, the amount of formazan product was determined by measuring the absorbance at $450 \mathrm{~nm}$ using a Sunrise Remote $\mathrm{R}^{\mathrm{TM}}$-micro plate reader (Tecan, Kawasaki, Japan) [37-39,46-50].

\subsection{Apoptosis Assay}

HASMCs were seeded into 12 -well plates $\left(3 \times 10^{5}\right.$ cells $/ 1 \mathrm{~mL} /$ well $)$ and incubated at $37^{\circ} \mathrm{C}$ in $5 \% \mathrm{CO}_{2}$ for $24 \mathrm{~h}$ in SmGM-2, followed by a 48 -h incubation with the indicated concentrations of vaspin. Cells were fixed with $4 \%$ paraformaldehyde. Terminal deoxynucleotidyl transferase-mediated deoxyuridine triphosphate-biotin nick end labeling (TUNEL) staining was then performed using an In Situ Apoptosis Detection Kit (Takara Bio, Kusatsu, Japan) as described previously [39,47-49].

\subsection{Foam Cell Formation Assay}

THP1 monocytes were seeded onto $3.5-\mathrm{cm}$ dishes $\left(1 \times 10^{6}\right.$ cells $/ 1 \mathrm{~mL} /$ dish $)$. Cells were incubated at $37^{\circ} \mathrm{C}$ in $5 \% \mathrm{CO}_{2}$ for 3 days in RPMI-1640 medium (Sigma) supplemented with $10 \%$ fetal bovine serum, $0.05 \mathrm{mg} / \mathrm{mL}$ streptomycin, and $50 \mathrm{U} / \mathrm{mL}$ penicillin (monocyte/macrophage conditioning medium (MCM)) and the indicated concentrations of vaspin in the presence of $150 \mathrm{ng} / \mathrm{mL}$ phorbol 12-myristate 13-acetate to induce differentiation into macrophages [47,48]. After that, THP1 monocyte-derived macrophages were incubated for 3 days in MCM with vaspin, and further incubated for 2 days in fresh MCM supplemented with vaspin, $50 \mu \mathrm{g} / \mathrm{mL}$ human oxidized LDL, and $100 \mu \mathrm{mol} / \mathrm{L}\left[{ }^{3} \mathrm{H}\right]$ oleate (PerkinElmer, Yokohama, Japan) conjugated with bovine serum albumin $[47,48]$. Cellular lipids were extracted and the radioactivity of cholesterol- $\left[{ }^{3} \mathrm{H}\right]$ oleate was determined by thin-layer chromatography.

\subsection{Western Blotting}

Aliquots of protein extracts $(20 \mu \mathrm{g})$ derived from THP1 monocytes, derived macrophages, HASMCs, HUVECs, and HAECs were separated by $10 \%$ sodium dodecyl sulfate-polyacrylamide gel electrophoresis, and then immunoblotted with specific antibodies raised against vaspin, and others as described previously [37-39,46-50].

\subsection{Administration of Vaspin into Mice}

Animal experiments were performed in accordance with the NIH Guidelines for the Care and Use of Laboratory Animals, with protocols approved by the Institutional Animal Care and Use Committee 
of Tokyo University of Pharmacy and Life Sciences (No. L15-08, 18 May 2015). A total of 25 male Apoe ${ }^{-/-}$mice (BALB/c. KOR/StmSlc-Apoe $e^{\text {shl }}$ mice) at the age of 9 weeks were purchased from Japan SLC and maintained on a normal diet until 13 weeks of age. Subsequently these mice were fed a high-cholesterol diet containing $1.25 \%$ cholesterol, 3.0\% lard, and $1.625 \%$ glucose (Oriental Yeast, Tokyo, Japan). At 17 weeks of age, 7 mice were sacrificed as pre-infusion controls. The remaining 18 were divided into 3 groups of 7, 5, and 6 mice, which were continuously infused with 3 doses of vaspin $(0,50,100 \mu \mathrm{g} /$ mouse, respectively) for a period of 4 weeks using osmotic mini-pumps (Alzet Model 1002; Durect, Cupertino, CA, USA). The average dosing rate of continuous infusion was calculated as $0,2.5,5 \mu \mathrm{g} / \mathrm{kg} / \mathrm{h}$, respectively. Once every 2 weeks, the mini-pumps were implanted subcutaneously into the dorsum under medetomidine-midazolam-butorphanol anesthesia [48].

At the experimental endpoint (before and 4 weeks after infusion), the $A p o e^{-/-}$mice were sacrificed by exsanguination (total blood collection) under medetomidine-midazolam-butorphanol anesthesia [48]. The whole aorta was immediately washed by perfusion with phosphate buffered saline and fixed with $4 \%$ formaldehyde. The aorta was excised from the aortic sinus to the abdominal area, and connective and adipose tissues were carefully removed [37-39,47-50].

\subsection{Animal Measurements}

Body weight and food intake were measured through the study. Systolic and diastolic blood pressures were measured using the indirect tail-cuff method (Kent Scientific, Torrington, CT, USA). At the experimental endpoint, blood samples were collected after a 4-h fast. Plasma levels of glucose, total cholesterol, triglyceride, and free fatty acid were measured by enzymatic methods (Denka Seiken, Tokyo, Japan) [37-39,47-50]. Non-HDL cholesterol was calculated as total cholesterol minus HDL cholesterol. Plasma insulin level was measured by enzyme-linked immunosorbent assay (Ultra-sensitive mouse insulin ELISA kit, Morinaga, Yokohama, Japan) [48]. The HOMA-IR was calculated as fasting plasma insulin $(\mathrm{pmol} / \mathrm{L}) \times 0.139$ (conversion to $\mu \mathrm{U} / \mathrm{mL}$ ) $\times$ fasting plasma glucose $(\mathrm{mg} / \mathrm{dL}) / 405$ [48].

\subsection{Assessment of Atherosclerotic Lesions}

The entire aorta lumen surface and cross-sections of the aortic sinus were stained with Oil Red $O$ for assessment of atherosclerotic lesion area and plaque size, respectively [37-39,47-50]. In aortic sinus wall, monocyte/macrophage infiltration, VSMC content, and vascular inflammation were visualized by staining with antibodies for MOMA2 (Millipore, Burlington, MA, USA), $\alpha$-SMA (Sigma, St. Louis, MO, USA), or pentraxin 3 (Bioss, Woburn, MA, USA), respectively [37-39,47-50]. The positive stained areas were traced by an investigator blind to the treatment and quantified by image analysis (Adobe Photoshop and NIH ImageJ).

\subsection{Statistical Analysis}

All values are expressed as means \pm SEM. The data were compared by the unpaired Student's $t$ test between 2 groups and 1-way analysis of variance followed by Bonferroni's post hoc test among $\geq 3$ groups using Statview-J 5.0 (SAS Institute, Cary, NC, USA). Statistical significance was defined as $p<0.05$.

Author Contributions: K.S. (Kengo Sato) designed the study, analyzed results, and contributed to write the manuscript. R.S. performed most of the experiments and analysis. M.Y., T.Y., K.S. (Koichiro Shibata), and T.O. carried out animal experiments. Y.M. measured animal blood samples. T.M. performed clinical sample collection and immunostaining. H.I.U. and T.H. contributed to data interpretation and discussion. T.W. co-wrote the manuscript and provided insights and critical review of the manuscript.

Funding: This work was supported in part by a Grant-in-Aid for Young Scientists (B) (25860418 to K.Sato), Grants-in-Aid for Scientific Research (C) (16K08943 to K.Sato and 17K08993 to T.W.) from the Japan Society for the Promotion of Science (JSPS), and a Grant-in-Aid for JSPS Fellows (DC2, 17J02716 to R.S.).

Acknowledgments: The authors thank Fumiko Itoh for her kind support and Eri Soeda, Karin Maeda, and Hiroe Kawana for their technical assistance. The authors also thank the Japanese Red Cross Society for the 
assignment of human blood plasma for LDL isolation (No. 25J0089, 24 January 2014). Presented in part at the 50th Annual Scientific Meeting of the Japan Atherosclerosis Society, Osaka, Japan, 12-14 July 2018.

Conflicts of Interest: All authors declare no conflict of interest.

\section{Abbreviations}

$\begin{array}{ll}\text { ABCA1 } & \text { ATP-binding cassette transporter A1 } \\ \text { ABCG1 } & \text { ATP-binding cassette transporter G1 } \\ \text { ACAT1 } & \text { Acyl-coenzyme A: cholesterol acyltransferase 1 } \\ \text { CAD } & \text { Coronary artery disease } \\ \text { ECM } & \text { Extracellular matrix } \\ \text { ER } & \text { Endoplasmic reticulum } \\ \text { HAEC } & \text { Human aortic endothelial cell } \\ \text { HASMC } & \text { Human aortic smooth muscle cell } \\ \text { HOMA-IR } & \text { Homeostasis model assessment of insulin resistance } \\ \text { HUVEC } & \text { Human umbilical vein endothelial cell } \\ \text { MCM } & \text { Monocyte/macrophage conditioning medium } \\ \text { MMP } & \text { Matrix metalloproteinase } \\ \text { NCEH } & \text { Neutral cholesterol ester hydrolase } \\ \text { NFKB } & \text { Nuclear factor } \text { kB } \\ \text { LDL } & \text { Low-density lipoprotein } \\ \text { PI3K } & \text { Phosphoinositide 3-kinase } \\ \text { PPAR } \gamma & \text { Peroxisome proliferator-activated receptor } \gamma \\ \text { ROS } & \text { Reactive oxygen species } \\ \text { SRB1 } & \text { Scavenger receptor class B type 1 } \\ \text { VSMC } & \text { vascular smooth muscle cell }\end{array}$

\section{References}

1. Hansson, G.K.; Libby, P. The immune response in atherosclerosis: A double-edged sword. Nat. Rev. Immunol. 2006, 6, 508-519. [CrossRef] [PubMed]

2. Tabas, I.; Bornfeldt, K.E. Macrophage phenotype and function in different stages of atherosclerosis. Circ. Res. 2016, 118, 653-667. [CrossRef] [PubMed]

3. Yu, X.H.; Fu, Y.C.; Zhang, D.W.; Yin, K.; Tang, C.K. Foam cells in atherosclerosis. Clin. Chim. Acta 2013, 424, 245-252. [CrossRef] [PubMed]

4. Igarashi, M.; Osuga, J.; Uozaki, H.; Sekiya, M.; Nagashima, S.; Takahashi, M.; Takase, S.; Takanashi, M.; Li, Y.; Ohta, K.; et al. The critical role of neutral cholesterol ester hydrolase 1 in cholesterol removal from human macrophages. Circ. Res. 2010, 107, 1387-1395. [CrossRef] [PubMed]

5. Rudijanto, A. The role of vascular smooth muscle cells on the pathogenesis of atherosclerosis. Acta Med. Indones. 2007, 39, 86-93. [PubMed]

6. Businaro, R.; Tagliani, A.; Buttari, B.; Profumo, E.; Ippoliti, F.; di Cristofano, C.; Capoano, R.; Salvati, B.; Riganò, R. Cellular and molecular players in the atherosclerotic plaque progression. Ann. N. Y. Acad. Sci. 2012, 1262, 134-141. [CrossRef] [PubMed]

7. Hida, K.; Wada, J.; Eguchi, J.; Zhang, H.; Baba, M.; Seida, A.; Hashimoto, I.; Okada, T.; Yasuhara, A.; Nakatsuka, A.; et al. Visceral adipose tissue-derived serine protease inhibitor: A unique insulin-sensitizing adipocytokine in obesity. Proc. Natl. Acad. Sci. USA 2005, 102, 10610-10615. [CrossRef] [PubMed]

8. Klöting, N.; Berndt, J.; Kralisch, S.; Kovacs, P.; Fasshauer, M.; Schön, M.R.; Stumvoll, M.; Blüher, M. Vaspin gene expression in human adipose tissue: Association with obesity and type 2 diabetes. Biochem. Biophys. Res. Commun. 2006, 339, 430-436. [CrossRef] [PubMed]

9. Tan, B.K.; Heutling, D.; Chen, J.; Farhatullah, S.; Adya, R.; Keay, S.D.; Kennedy, C.R.; Lehnert, H.; Randeva, H.S. Metformin decreases the adipokine vaspin in overweight women with polycystic ovary syndrome concomitant with improvement in insulin sensitivity and a decrease in insulin resistance. Diabetes 2008, 57, 1501-1507. [CrossRef] [PubMed] 
10. Li, H.L.; Peng, W.H.; Cui, S.T.; Lei, H.; Wei, Y.D.; Li, W.M.; Xu, Y.W. Vaspin plasma concentrations and mRNA expressions in patients with stable and unstable angina pectoris. Clin. Chem. Lab. Med. 2011, 49, 1547-1554. [PubMed]

11. Spiroglou, S.G.; Kostopoulos, C.G.; Varakis, J.N.; Papadaki, H.H. Adipokines in periaortic and epicardial adipose tissue: Differential expression and relation to atherosclerosis. J. Atheroscler. Thromb. 2010, 17, 115-130. [CrossRef] [PubMed]

12. Klöting, N.; Kovacs, P.; Kern, M.; Heiker, J.T.; Fasshauer, M.; Schön, M.R.; Stumvoll, M.; Beck-Sickinger, A.G.; Blüher, M. Central vaspin administration acutely reduces food intake and has sustained blood glucose-lowering effects. Diabetologia 2011, 54, 1819-1823. [CrossRef] [PubMed]

13. Tanaka, N.; Patel, K.; Moore, A.E.; Dulnoan, D.; Edwards, S.; Hampson, G. The relationship between circulating adiponectin, leptin and vaspin with bone mineral density (BMD), arterial calcification and stiffness: A cross-sectional study in post-menopausal women. J. Endocrinol. Investig. 2017, 40, 1345-1353. [CrossRef] [PubMed]

14. Fasshauer, M.; Blüher, M. Adipokines in health and disease. Trends Pharmacol. Sci. 2015, 36, 461-470. [CrossRef] [PubMed]

15. Phalitakul, S.; Okada, M.; Hara, Y.; Yamawaki, H. Vaspin prevents methyglyoxal-induced apoptosis in human vascular endothelial cells by inhibiting reactive oxygen species generation. Acta Physiol. 2013, 209, 212-219.

16. Liu, S.; Dong, Y.; Wang, T.; Zhao, S.; Yang, K.; Chen, X.; Zheng, C. Vaspin inhibited proinflammatory cytokine induced activation of nuclear factor- $\mathrm{kB}$ and its downstream molecules in human endothelial EA.hy 926 cells. Diabetes Res. Clin. Pract. 2014, 103, 482-488. [CrossRef] [PubMed]

17. Jung, C.H.; Lee, M.J.; Kang, Y.M.; Lee, Y.L.; Yoon, H.K.; Kang, S.W.; Lee, W.J.; Park, J.Y. Vaspin inhibits cytokine-induced nuclear factor-kappa B activation and adhesion molecule expression via AMP-activated protein kinase activation in vascular endothelial cells. Cardiovasc. Diabetol. 2014, 13, 41. [CrossRef] [PubMed]

18. Phalitakul, S.; Okada, M.; Hara, Y.; Yamawaki, H. A novel adipocytokine, vaspin inhibits platelet-derived growth factor-BB-induced migration of vascular smooth muscle cells. Biochem. Biophys. Res. Commun. 2012, 423, 844-849. [CrossRef] [PubMed]

19. Li, H.; Peng, W.; Zhuang, J.; Lu, Y.; Jian, W.; Wei, Y.; Li, W.; Xu, Y. Vaspin attenuates high glucose-induced vascular smooth muscle cells proliferation and chemokinesis by inhibiting the MAPK, PI3K/Akt, and NF- $\mathrm{KB}$ signaling pathways. Atherosclerosis 2013, 228, 61-68. [CrossRef] [PubMed]

20. Gao, J.H.; Zeng, M.Y.; Yu, X.H.; Zeng, G.F.; He, L.H.; Zheng, X.L.; Zhang, D.W.; Ouyang, X.P.; Tang, C.K. Visceral adipose tissue-derived serine protease inhibitor accelerates cholesterol efflux by up-regulating ABCA1 expression via the NF- $\mathrm{BB} / \mathrm{miR}-33$ a pathway in THP-1 macropahge-derived foam cells. Biochem. Biophys. Res. Commun. 2018, 500, 318-324. [CrossRef] [PubMed]

21. Nakatsuka, A.; Wada, J.; Iseda, I.; Teshigawara, S.; Higashio, K.; Murakami, K.; Kanzaki, M.; Inoue, K.; Terami, T.; Katayama, A.; et al. Vaspin is an adipokine ameliorating ER stress in obesity as a ligand for cell-surface GRP78/MTJ-1 complex. Diabetes 2012, 61, 2823-2832. [CrossRef] [PubMed]

22. Lin, Y.; Zhuang, J.; Li, H.; Zhu, G.; Zhou, S.; Li, W.; Peng, W.; Xu, Y. Vaspin attenuates the progression of atherosclerosis by inhibiting ER stress-induced macrophage apoptosis in apoE ${ }^{-/-}$mice. Mol. Med. Rep. 2016, 13, 1509-1516. [CrossRef] [PubMed]

23. Nakatsuka, A.; Wada, J.; Iseda, I.; Teshigawara, S.; Higashio, K.; Murakami, K.; Kanzaki, M.; Inoue, K.; Terami, T.; Katayama, A.; et al. Visceral adipose tissue-derived serine proteinase inhibitor inhibits apoptosis of endothelial cells as a ligand for the cell-surface GRP78/voltage-dependent anion channel complex. Circ. Res. 2013, 112, 771-780. [CrossRef] [PubMed]

24. Youn, B.S.; Klöting, N.; Kratzsch, J.; Lee, N.; Park, J.W.; Song, E.S.; Ruschke, K.; Oberbach, A.; Fasshauer, M.; Stumvoll, M.; Blüher, M. Serum vaspin concentrations in human obesity and type 2 diabetes. Diabetes 2008, 57, 372-377. [CrossRef] [PubMed]

25. El-Mesallamy, H.O.; Kassem, D.H.; El-Demerdash, E.; Amin, A.I. Vaspin and visfatin/Nampt are interesting interrelated adipokines playing a role in the pathogenesis of type 2 diabetes mellitus. Metabolism 2011, 60, 63-70. [CrossRef] [PubMed]

26. Esteghamati, A.; Noshad, S.; Mousavizadeh, M.; Zandieh, A.; Nakhjavani, M. Association of vaspin with metabolic syndrome: The pivotal role of insulin resistance. Diabetes Metab. J. 2014, 38, 143-149. [CrossRef] [PubMed] 
27. Choi, S.H.; Kwak, S.H.; Lee, Y.; Moon, M.K.; Lim, S.; Park, Y.J.; Jang, H.C.; Kim, M.S. Plasma vaspin concentrations are elevated in metabolic syndrome in men and are correlated with coronary atherosclerosis in women. Clin. Endocrinol. 2011, 75, 628-635. [CrossRef] [PubMed]

28. Sathyaseelan, A.J.; Adole, P.S.; Wyawahare, M.; Saya, R.P. Assessment of serum vaspin levels among type 2 diabetes mellitus patients with or without acute coronary syndrome. J. Clin. Diagn. Res. 2016, 10, BC07-BC10. [CrossRef] [PubMed]

29. Zhang, B.; Peng, W.; Li, H.; Lu, Y.; Zhuang, J.; Wang, K.; Su, Y.; Xu, Y. Plasma vaspin concentrations are decreased in acute coronary syndrome, but unchanged in patients without coronary lesions. Clin. Biochem. 2013, 46, 1520-1525. [CrossRef] [PubMed]

30. Kobat, M.A.; Celik, A.; Balin, M.; Altas, Y.; Baydas, A.; Bulut, M.; Aydin, S.; Dagli, N.; Yavuzkir, M.F.; Ilhan, S. The investigation of serum vaspin level in atherosclerotic coronary artery disease. J. Clin. Med. Res. 2012, 4, 110-113. [CrossRef] [PubMed]

31. Kadoglou, N.P.; Gkontopoulos, A.; Kapelouzou, A.; Fotiadis, G.; Theofilogiannakos, E.K.; Kottas, G.; Lampropoulos, S. Serum levels of vaspin and visfatin in patients with coronary artery disease-Kozani study. Clin. Chim. Acta 2011, 412, 48-52. [CrossRef] [PubMed]

32. Liu, S.; Li, X.; Wu, Y.; Duan, R.; Zhang, J.; Du, F.; Zhang, Q.; Li, Y.; Li, N. Effects of vaspin on pancreatic $\beta$ cell secretion via PI3K/Akt and NF-kB signaling pathways. PLoS ONE 2017, 12, e0189722. [CrossRef] [PubMed]

33. Heiker, J.H.; Klöting, N.; Kovacs, P.; Kuettner, E.B.; Sträter, N.; Schultz, S.; Kern, M.; Stumvoll, M.; Blüher, M.; Beck-Sickinger, A.G. Vaspin inhibits kallikrein 7 by serpin mechanism. Cell. Mol. Life Sci. 2013, 70, 2569-2583. [CrossRef] [PubMed]

34. Zieger, K.; Weiner, J.; Krause, K.; Schwarz, M.; Kohn, M.; Stumvoll, M.; Blüher, M.; Heiker, J.T. Vaspin suppresses cytokine-induced inflammation in 3T3-L1 adipocytes via inhibition of NFKB pat hway. Mol. Cell. Endocrinol. 2018, 460, 181-188. [CrossRef] [PubMed]

35. Jung, C.H.; Lee, W.J.; Hwang, J.Y.; Seol, S.M.; Kim, Y.M.; Lee, Y.L.; Park, J.Y. Vaspin protects vascular endothelial cells against free fatty acid-induced apoptosis through a phosphatidylinositol 3-kinase/Akt pathway. Biochem. Biophys. Res. Commun. 2011, 413, 264-269. [CrossRef] [PubMed]

36. Sun, N.; Wang, H.; Wang, L. Vaspin alleviates dysfunction of endothelial progenitor cells induced by high glucose via PI3K/Akt/eNOS pathway. Int. J. Clin. Exp. Pathol. 2015, 8, 482-489. [PubMed]

37. Watanabe, K.; Watanabe, R.; Konii, H.; Shirai, R.; Sato, K.; Matsuyama, T.; Ishibashi-Ueda, H.; Koba, S.; Kobayashi, Y.; Hirano, T.; et al. Counteractive effects of omentin-1 against atherogenesis. Cardiovasc. Res. 2016, 110, 118-128. [CrossRef] [PubMed]

38. Watanabe, R.; Watanabe, H.; Takahashi, Y.; Kojima, M.; Konii, H.; Watanabe, K.; Shirai, R.; Sato, K.; Matsuyama, T.; Ishibashi-Ueda, H.; et al. Atheroprotective effects of tumor necrosis factor-stimulated gene-6. JACC. Basic Transl. Sci. 2016, 6, 494-509. [CrossRef]

39. Shirai, R.; Sato, K.; Yamashita, T.; Yamaguchi, M.; Okano, T.; Watanabe-Kominato, K.; Watanabe, R.; Matsuyama, T.; Ishibashi-Ueda, H.; Koba, S.; et al. Neopterin counters vascular inflammation and atherosclerosis. J. Am. Heart Assoc. 2018, 7, e007359. [CrossRef] [PubMed]

40. Loppnow, H.; Libby, P. Adult human vascular endothelial cells express the IL6 gene differentially in response to LPS or IL1. Cell. Immunol. 1989, 122, 493-503. [CrossRef]

41. Holst, J.J.; Ehrhart-Bornstein, M.; Messell, T.; Poulsen, S.S.; Harling, H. Release of galanin from isolated perfused porcine adrenal glands: Role of splanchnic nerves. Am. J. Physiol. 1991, 261, E31-E40. [CrossRef] [PubMed]

42. Barzegari, A.; Mahdirejei, H.A. Effects of 8 weeks resistance training on plasma vaspin and lipid profile levels in adult men with type 2 diabetes. Caspian J. Intern. Med. 2014, 5, 103-108. [PubMed]

43. Esteghamati, A.; Mousavizadeh, M.; Noahad, S.; Zandieh, A.; Zarei, H.; Nakhjavani, M. Gender-dependent effects of metformin on vaspin and adiponectin in type 2 diabetes patients: A randomized clinical trial. Horm. Metab. Res. 2013, 45, 319-325. [CrossRef] [PubMed]

44. Al-Kuraishy, H.M.; Al-Gareeb, A.I.; Al-Buhadilly, A.K. Rosuvastatin improves vaspin serum levels in obese patients with acute coronary syndrome. Diseases 2018, 6, 9. [CrossRef] [PubMed]

45. Takayama, T.; Hiro, T.; Yoda, S.; Fukamachi, D.; Haruta, H.; Kogo, T.; Mineki, T.; Murata, H.; Oshima, T.; Hirayama, A. Effect of Aggressive lipid-lowering treatment with Rosuvastatin on vascular endoTHelium function: Evaluation of vascular endothelium function (EARTH study). Heart Vessel. 2017, 33, 590-594. [CrossRef] [PubMed] 
46. Naito, C.; Hashimoto, M.; Watanabe, K.; Shirai, R.; Takahashi, Y.; Kojima, M.; Watanabe, R.; Sato, K.; Iso, Y.; Matsuyama, T.; et al. Facilitatory effects of fetuin-A on atherosclerosis. Atherosclerosis 2016, 246, 344-351. [CrossRef] [PubMed]

47. Kojima, M.; Ozawa, N.; Mori, Y.; Takahashi, Y.; Watanabe-Kominato, K.; Shirai, R.; Watanabe, R.; Sato, K.; Matsuyama, T.; Ishibashi-Ueda, H.; et al. Catestatin prevents macrophage-driven atherosclerosis but not arterial injury-induced neointimal hyperplasia. Thromb. Haemost. 2018, 118, 182-194. [CrossRef] [PubMed]

48. Takahashi, Y.; Watanabe, R.; Sato, Y.; Ozawa, N.; Kojima, M.; Watanabe-Kominato, K.; Shirai, R.; Sato, K.; Hirano, T.; Watanabe, T. Novel phytopeptide osmotin mimics preventive effects of adiponectin on vascular inflammation and atherosclerosis. Metabolism 2018, 83, 128-138. [CrossRef] [PubMed]

49. Sato, K.; Shirai, R.; Hontani, M.; Shinooka, R.; Hasegawa, A.; Kichise, T.; Yamashita, T.; Yoshizawa, H.; Watanabe, R.; Matsuyama, T.; et al. Potent vasoconstrictor kisspeptin-10 induces atherosclerotic plaque progression and instability: Reversal by its receptor GPR54 antagonist. J. Am. Heart Assoc. 2017, 6, e005790. [CrossRef] [PubMed]

50. Konii, H.; Sato, K.; Kikuchi, S.; Okiyama, H.; Watanabe, R.; Hasegawa, A.; Yamamoto, K.; Itoh, F.; Hirano, T.; Watanabe, T. Stimulatory effects of cardiotrophin 1 on atherosclerosis. Hypertension 2013, 62, 942-950. [CrossRef] [PubMed]

(C) 2018 by the authors. Licensee MDPI, Basel, Switzerland. This article is an open access article distributed under the terms and conditions of the Creative Commons Attribution (CC BY) license (http:/ / creativecommons.org/licenses/by/4.0/). 